\title{
Minneord >
}

\section{Arne Sund}

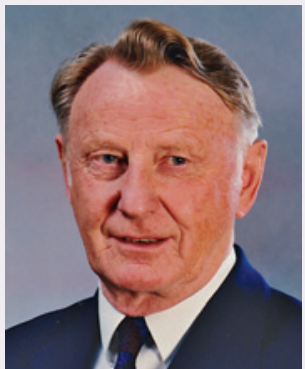

Professor dr.med. Arne Sund er død, 86 år gammel. Etter oppvekst i Grue og motstandsinnsats under krigen utdannet han seg til lege og tjenestegjorde deretter i Tysklandsbrigaden. I 1952 var han ved det norske feltsykehuset i Korea og fikk førstehåndserfaring med stressreaksjonene hos stridende og sårede amerikanske soldater og med sivilbefolkningens krigspåkjenninger. I unge år deltok Arne Sund i to kriger. Han skulle bli et viktig tidsvitne. Erfaringene skulle bli bestemmende for hans senere legegjerning og virke innen psykiatrien. Men først skaffet han seg bred erfaring gjennom allmennpraksis i Hønefoss. Som sjefspsykiater i Forsvaret bygde han opp norsk militærpsykiatri til å bli ledende innen NATO. Som administrerende overlege ved Universitetets psykiatriske klinikk etablerte han det første kriseteam i 1974.

I 1978 ble Sund utnevnt til professor i katastrofepsykiatri, den første akademiske stilling innen feltet i verden. Det kan virke overraskende at et fredelig sted som Norge skulle bli et foregangsland i forskning på virkning av massedød, krig, katastrofer, terror, tortur, ulykker og alle slags vold. Men kloke hoder blant krigsgenerasjonens medlemmer ville sikre at dyrekjøpte erfaringer om motstandskraft og sårbarhet ikke skulle glemmes, men leve videre også når de var borte, og at kunnskapen skulle videreutvikles. De visste at alt kan skje. Arne
Sunds læring var basert på egne opplevelser. Hans bearbeidet disse til å bli erfaringer, og gjennom forskningen han startet ble de etter hvert vitenskapelig dokumentert kunnskap. Det er grunnlag for å si at mange av de tiltak som ble satt inn etter terrorangrepene 22. juli 2011 var basert på forskning som Arne Sund tok initiativ til for snart 40 år siden.

Allerede i 1957 hadde en forskergruppe med norske leger begynt å kartlegge de helseskadelige følgene av det mest ekstreme voldsmiljø verden til nå har sett - de nazistiske dødsleirene. Disse pionerstudiene la en vesentlig del av kunnskapsgrunnlaget for fagfeltet psykotraumatologi. Mens Leo Eitinger dermed ble grunnleggeren av den medisinske viktimologien, læren om aggresjonens virkning på ofrene, ble Sund en av grunnleggerne av katastrofepsykiatrien, et fag som har fått $\varnothing$ kende internasjonal betydning. Globalt er katastrofer et alvorlig og økende problem, særlig i fattige land.

Etter at han ble pensjonist, viet han seg til arbeid innen bedriftshelsetjeneste og arbeidsmiljø. Han engasjerte seg helt til det siste sterkt i å filmatisere og dermed levendegjøre lokalhistoriske skikkelser på Ringerike.

Arne Sunds innsats som lege, lærer og forsker har hatt stor og ofte avgjørende betydning for mange mennesker, her hjemme og ute. Han vil bli savnet av Idun og familien og av pasienter og kolleger. Et betydelig livsverk står igjen til minne om ham.

\section{Lars Weisæth, Ulrik Fredrik Malt}

\section{Meldte dødsfall}

Dødsfall kan meldes til Legeforeningens registerseksjon ved Torill Skjærholt, tlf. 23109197 eller register@legeforeningen.no

\section{Steinar Aune}

5.2. $1955-25.12 .2011$

Finn Karsten Finsnes

7.11. 1919-30.12. 2011

Bjarne Halleraker

10.9. 1930-20.10. 2011

\section{Christine Herzog \\ 25.3. 1965-17.12. 2011}

Guri Hvammen

10.4. 1929-29.10. 2011

Kai Otto Lindbeck

22.6. 1940-19.12. 2011
Per Martem

25.7. 1928-11.12. 2011

Eilif Natrud

25.6. 1936-25.12. 2011

Alf Halvor Sogn

20.3. 1915-12.12. 2011
Gabriel Philip Stiris 30.11. 1920-30.11. 2011

Helge Toralf Øverland 21.7. 1918-28.11. 2011 